К. : Київ. нац. торг.- екон. ун-т, 2010. - 280 с. 3. Марцин В. С. Основи наукових досліджень: [навч. посіб.] / Марцин В. С., Міценко Н. Г., Даниленко О. А. та ін. - Л. : Ромус-Поліграф, 2002. - 128 с. 4. Мигаль В. Д. Теорія і методи наукової творчості: [навч. посіб.] / В. Д. Мигаль. - Х. : ВД «ІНЖЕК», 2007. - 424 с. 5. Пушкарь А. И. Основы научных исследований и организация научноисследовательской деятельности : [учеб. пособ.] / А. И. Пушкарь, Л. В. Потрашкова. -Х. : ИНЖЭК, 2006. - 280 с. 6. Стеченко Д. М. Методологія наукових досліджень: [підручник] / Д. М. Стеченко, О. С. Чмир. - [2-ге вид., перероб. і доп.]. - К. : Знання, 2007. -317 с. 7. Цехмістрова Г. С. Основи наукових досліджень: [навч. посіб.] / Г. С. Цехмістрова. - К. : ВД «Слово», 2004. - 240 с.

УДК 371.322:378.126:147

Андрій Кучерявий

\title{
АСПЕКТ ДІЯЛЬНОСТІ ПЕДАГОГА В СИСТЕМІ ПРОЕКТУВАЛЬНИХ ПРИНЦИПІВ УПРАВЛІННЯ САМОСТІЙНОЮ РОБОТОЮ МАЙБУТНІХ ЮРИСТІВ
}

Кучерявий А. О. Аспект діяльності педагога в системі проектувальних принципів управління самостійною роботою майбутніх юристів.

У статті розглянуто стан вивчення проблеми діяльності педагога 3 урахуванням проектувальних принципів управління самостійною навчальною діяльністю майбутніх юристів. Досліджено групу проектувальних принципів, які визначають складники діяльності викладача.

Ключові слова: діяльність педагога, педагогічне управління, самостійна робота, проектувальні принципи, студенти.

Кучерявый А. А. Аспект деятельности педагога в системе проектировочных принципов управления самостоятельной работой будущих юристов.

В статье рассмотрено состояние изученности проблемы деятельности педагога с учетом проектировочных принципов управления самостоятельной учебной деятельности будущих юристов. Исследована группа проектировочных принципов, которые определяют составляющие деятельности преподавателя.

Ключевые слова: деятельность педагога, педагогическое управление, самостоятельная работа, проектировочные принципы, студенты.

Kucheryaviy A. O. Aspect of the activity of the pedagogue in the system of projecting principles of management of independent work of future lawyers.

The problem of insufficient research of activity of the pedagogue in the projecting principles of management of independent educational activity of future lawyers is considered. The group of the projecting principles that determine the row of constituents of activity of professor is investigational.

Key words: activity of the pedagogue, pedagogical management, independent work, projecting principles, students.

Організація самостійної роботи студентів є одним із напрямів роботи викладача вищого закладу освіти, що вимагає вивчення питань управління самостійною навчальною діяльністю, зокрема управління педагогічного. Як і будь-яка діяльність, педагогічне управління та його базовий складник, яким є проектування самостійної роботи, грунтуються на певних принципах. Частина цих принципів має визначати складники функціональної діяльності викладача у процесі проектування та організації самостійної роботи студентів, зокрема майбутніх юристів, однак це питання залишається недостатньо вивченим сучасними науковцями. Отже, маємо констатувати проблему невідповідності ступеня значущості питань управління самостійною роботою студентів та стану вивченості функціональної діяльності педагога в її проектувальних принципах. Розв'язання цієї проблеми разом із визначенням груп принципів, присвячених базовим елементам моделювання, добору навчальних завдань та врахуванню особистісного складника, відкриває можливість переходу досліджень у цій галузі на рівень створення безпосередніх технологій проектування самостійної навчальної діяльності студентів юридичних спеціальностей. А перспектива забезпечення викладачів вищих юридичних закладів зазначеними технологіями зумовлює актуальність нашого дослідження. 
Сучасна педагогічна наука ретельно вивчає феномен самостійної роботи студента. Низка досліджень українських та зарубіжних науковців присвячена різним аспектам її організації [1; $5 ; 6]$, виконання [2; 3], функціональним характеристикам [4], покладеним в основу цієї роботи. Проте недостатньо наукових робіт, присвячених проблематиці управління самостійною навчальною діяльністю, зокрема питанням педагогічного управління. Залишаються нерозглянутими проектувальна діяльність викладача та аспекти діяльності педагога в системі проектувальних принципів управління самостійною роботою студентів юридичних спеціальностей.

Meта статті - дослідження групи проектувальних принципів управління самостійною роботою студентів юридичних спеціальностей, які $\epsilon$ визначальними для низки складників функціональної діяльності викладача. Завданнями дослідження $\epsilon$ розгляд принципів, що зумовлюють створення викладачем методичного супроводу самостійної роботи, забезпечення комунікації між педагогом і студентом та здійснення педагогічного самоаналізу.

Першим є принцип системного методичного супроводу самостійної навчальної діяльності, який забезпечує саме викладач. У педагогічній науці неодноразово підкреслювалася важливість методичного забезпечення навчальної діяльності загалом. Дослідимо можливий вплив його окремих складників на стан самостійної роботи студента з урахуванням його юридичної спеціальності. Задля цього розглянемо деякі особливості укладання зазначених складників методичного забезпечення:

1. Теоретичний матеріал, необхідний для виконання вправ, - умова якісної підготовки студента до виконання завдань. Зазначений матеріал, як правило, передбачає приклади виконання вправ, містить елементи алгоритмізації (як за змістом, так і за формою виконання) тощо. Якщо навчальна дисципліна $є$ правовою, питання щодо його відповідності юридичній професій не виникає. Проте по-різному може здійснити добір навчального матеріалу викладач неюридичних навчальних курсів. Навіть якщо добір прикладів та інших елементів теоретичної частини $\epsilon$ випадковим, педагог при цьому не порушує нормативних вимог викладання навчальної дисципліни, але втрачає можливість забезпечення умов професійного зростання студента. Він може врахувати особливості загальноосвітнього навчального предмета й професії юриста та наповнити зміст методичного забезпечення інформацією і прикладами виконання дій, зокрема комунікативних, письмових, розумових та ін., близьких до діяльності юриста. Такий добір матеріалу викладачеві не складно реалізувати під час подачі теоретичних відомостей з логіки, української мови за професійним спрямуванням, психології, іноземної мови, філософії тощо.

2. Мета виконання завдань. Вони можуть мати як загальний характер, якщо викладач непрофільних дисциплін не прив'язується до специфіки юридичної діяльності, так і бути конкретизованими в аспекті виконання окремих завдань професійної підготовки юриста. Головною особливістю формулювання мети $є$ особистісна зорієнтованість, потенціальна можливість стати власною для кожного студента, що передбачає її конкретизацію та зв'язок 3 професійною діяльністю майбутнього фахівця. Саме в такому випадку можливо досягти самореалізації особистості.

3. Логіко-композиційна структура організації пізнавальної діяльності майбутнього юриста. Фундаментальними елементами цієї структури є теоретичний матеріал, безпосередні завдання та заходи контролю виконання самостійної роботи. Типовими способами організації пізнання студентів $є$ дедуктивний, індуктивний та аналогійний. Доцільність використання дедуктивного способу пізнання (від загального до конкретного) зумовлена схожістю його логічної побудови 3 типовими ситуаціями в практичній роботі юриста. Наприклад, загальним аспектом у навчанні $\epsilon$ теоретичний розгляд поняття, у юридичній роботі - інформація фабули злочину. У такому випадку конкретним для навчання $€$ 3'ясування окремих властивостей поняття через розв'язання низки спеціально дібраних завдань, а для юридичної діяльності - причин, обставин та наслідків правопорушення. У результаті в навчальній ситуації відбувається системне оволодіння студентом навчальним матеріалом: розуміння ним сутності поняття, його складників, їхніх властивостей та зв'язків між ними, зовнішніх зв'язків об'єкта дослідження тощо. Юрист же набуває системного володіння ситуацією, яка вимагає подальшої юридичної оцінки та відповідних дій, наприклад, слідчого або адвоката. Отже, застосування дедуктивного способу пізнавальної діяльності студента має використовуватися як складник його підготовки до юридичної практики. 
Певної значущості для становлення майбутнього юриста має й індуктивний характер організації навчання (від конкретного до загального). Наприклад, така ситуація, як виконання окремих вправ 3 подальшим теоретичним узагальненням результатів, є подібною до суто правової - проведення процесуальних дій та встановлення провини певної особи.

Аналогійний спосіб організації пізнавальної діяльності студентів широко використовується під час самостійної роботи. Наприклад, так зручно організовувати засвоєння схожих за змістом моделей чи алгоритмів, безпосереднє навчальне завдання може бути сформульоване як пошук схожості об'єктів та відмінності між ними тощо. Водночас аналогійний спосіб використовується і в юридичній діяльності, зокрема, якщо йдеться про типові ситуації в роботі слідчого, адвоката, прокурора. Це є свідченням необхідності використання аналогійного способу організації пізнавальної діяльності студентів як засобу професійної підготовки юриста.

4. Наявність контролю виконання завдань. Провідна властивість засобів контролю самостійної роботи полягає в можливості їх трансформації в самоконтроль. Студент за певними критеріями повинен особисто оцінювати якість виконаної роботи, а студент-юрист ще й $з$ точки зору набуття фахової компетентності. Критерії мають бути чітко, однозначно визначеними та характеризуватися відповідністю фаховій підготовці.

Створене викладачем методичне забезпечення відповідно до навчальної програми та 3 урахуванням спеціальності студентів забезпечує ефективність їхньої самостійної роботи та реалізує завдання вищого юридичного навчального закладу щодо формування особистості фахівця.

Другим принципом, зміст якого відповідає меті нашого дослідження, $є$ принцип неперервності зворотнього зв'язку між викладачем і студентами на всіх етапах організації самостійної навчальної діяльності майбутніх фахівців.

Цей принцип частково забезпечує умови управління самостійною навчальною діяльністю студентів загалом, оскільки дозволяе визначити якість створеної педагогічної системи, своєчасно реагувати на виявлені недоліки на різних етапах організації навчання і самостійної роботи зокрема, формулювати дидактичну мету та добирати завдання для самостійного виконання. Зворотній зв'язок є наслідком утвореного викладачем каналу комунікації. Ї̈і якість забезпечується різноманітністю використання форм взаємодії, зокрема безпосередньої (на аудиторних заняттях, під час проведення консультацій), часткової (наприклад, перевірка зошитів за відсутності студента), дистанційної з використанням Інтернет-ресурсу та латентної, яка носить постійний характер та грунтується на спостереженні викладача за розвитком студента. Під час використання кожної 3 них можливе врахування специфіки юридичної професії студента: спілкування має носити діловий характер, характеризуватися рівністю прав його суб'єктів під час відстоювання позиції, а правила комунікації, права та обов'язки ії сторін $\epsilon$ визначеними, стабільними і не допускають винятків.

Відсутність зворотнього зв'язку або неефективність каналу комунікації призводять до втрати викладачем здатності управління процесом навчання взагалі. Тому забезпечення необхідного взаємозв'язку є одним з найбільш важливих складників організації самостійної роботи студентів-юристів.

Розглянемо принцип оптимальності педагогічного самоаналізу ступеня ефективності організації самостійної навчальної діяльності майбутніх юристів. Системне розуміння викладачем процесу навчання забезпечує пошук шляхів удосконалення самостійної роботи студентів, якій властиві певні функціональні характеристики (системоутворювальна, ціліснозабезпечувальна, якісного засвоєння навчального матеріалу, управлінська, зворотнього зв'язку, забезпечення неперервності освіти) та низка функцій, спеціально зорієнтованих на становлення особистості майбутнього фахівця. На підставі аналізу результатів їх реалізації й має здійснюватися самоаналіз викладача 3 точки зору достатності та ефективності організованої ним самостійної роботи студента. Зокрема, маємо такі параметри самоаналізу викладача щодо проектування окремих модулів самостійної роботи:

1. Тематичної належності: чи відповідає зміст завдання певній темі. У випадку, наприклад, міжпредметних завдань належність має визначатися щодо конкретних тем різних дисциплін, а узагальнювальні вправи мають відбивати зміст низки тем з одного предмета.

2. Цільової визначеності: чи наявні конкретні цілі (дидактичні, виховні, розвивальні) модуля самостійної роботи, наскільки вони відповідають цілям вивчення навчальної дисципліни та поточному етапу засвоєння матеріалу. 
3. Цілісного забезпечення процесу навчання: чи утворюється структурна цілісність процесу засвоєння навчального матеріалу в результаті сукупності аудиторної та самостійної форм роботи студентів.

4. Якісного засвоєння навчального матеріалу: наскільки рівень засвоєння студентами навчального матеріалу досягнутий (буде досягнутий) у результаті виконання завдань самостійної роботи та відповідає очікуванням викладача, логіці навчального процесу і вимогам навчальної програми.

5. Активізації діяльності студентів: чи відповідає зміст самостійної роботи професійним потребам майбутнього юриста в самореалізації й загального розвитку.

6. Забезпеченості зворотнього зв'язку: чи реалізується потреба викладача в поточному та підсумковому контролі виконання студентом самостійної роботи, якою мірою може розраховувати студент на допомогу викладача в разі виникнення певних труднощів, чи відповідає характер комунікації засадам професійного (юридичного) спілкування студента.

7. Відповідності загальному процесу підготовки: чи відповідає безпосередня самостійна навчальна діяльність студента логіці навчального процесу у вищому навчальному закладі взагалі, його меті та завданням підготовки юриста. Як ураховано та використано базові знання та уміння, чи будуть використані набуті знання й уміння під час вивчення інших тем, навчальних дисциплін та у професійній діяльності юриста.

8. Урахування індивідуальних та типологічних особливостей студентів: чи враховано вікові особливості студентів, їхній досвід навчання у вищому закладі освіти, досвід професійної діяльності, загальний рівень розвитку, зони актуального розвитку; якою мірою оптимально знайдено форми виконання завдань (індивідуальна, групова) або їх види (написання проектів, підготовка доповідей, робота з Інтернет-ресурсом) тощо. Чи зорієнтовані завдання для самостійної роботи на розвиток розумової діяльності студента? Як ураховано під час добору завдань те, що їх мають виконувати як сильні, так і слабкі студенти? Чи відповідає добір завдань особливостям юридичної професії. Чи використано всі можливості наближення змісту завдань до змісту діяльності юриста?

9. Методичної забезпеченості: чи створено достатні умови для виконання студентами запропонованих завдань $з$ позиції організації їхньої самостійної навчальної роботи, наявності для цього необхідного теоретичного матеріалу або чітких посилань на певні джерела, необхідні для виконання вправ, прикладів, критеріїв оцінки отриманих результатів тощо. Чи реалізовано організацію пізнавальної діяльності студента в спосіб, що відповідає типовим ситуаціям професійної діяльності юриста.

Педагогічний самоаналіз забезпечення ефективності організації самостійної діяльності студентів передбачає рефлексивні роздуми викладача щодо проекту кожного модуля самостійної роботи як під час планування завдань, так і після їх виконання студентами. Виявлені недоліки у проектуванні передбачають редагування змісту і кількості завдань, зміни цільового призначення вправ, корекції методичного забезпечення.

Висновки щодо наукових результатів проведеного дослідження полягають у тому, що під час розгляду наведених принципів визначено структурні та процесуальні особливості педагогічної діяльності під час здійснення управління самостійною роботою студентів юридичних спеціальностей. Охарактеризовані принципи стосуються функціональної діяльності педагога і регламентують створення ним змістово зоріснтованого на професію юриста методичного супроводу самостійної роботи студентів, організацію зворотнього зв'язку між викладачем і студентами та проведення педагогічного самоаналізу. Перспектива подальших розвідок полягає в розробленні переліку та змісту етапів проектування самостійної навчальної діяльності студентів як основи педагогічного управління.

\section{Література}

1. Жуков А. Е. Организация самостоятельной работы студентов в высшей школе. Дидактические средства, технологии, программы: [монография] / А. Е. Жуков, А. В. Симоненко. - М.: ЮНИТИДАНА, 2004. - 220 с. 2. Зубра А. С. Культура умственного труда студента : [пособ. для студ. высших учеб. заведений] / А. С. Зубра. - Минск : Дикта, 2006. - 228 с. 3. Кучерявий А. О. Основи самостійної навчальної діяльності :[навч. посіб.]/ А. О. Кучерявий, М. В. Балко. - Донецьк : ДЮІ ЛДУВС ім. Е. О. Дідоренка, 2010. - 204 с. 4. Кучерявий А. О. Функціональні характеристики самостійної роботи майбутніх юристів у контексті управління самостійною навчальною діяльністю студентів / А. О. Кучерявий // Наукові праці Донецького національного технічного університету. - 2012. - 
Вип. 11. - С. 95-98. 5. Малихін О. В. Теоретико-методологічні засади організації самостійної навчальної діяльності студентів вищих навчальних закладів : дис. ... д-ра пед. наук: спец. 13.00.09 / О. В. Малихін; Криворіз. держ. пед. ун-т. - Кривий Ріг, 2009. - 504 с. 6. Солдатенко М. М. Теорія і практика самостійної пізнавальної діяльності: [монографія] / М. М. Солдатенко. - К. : Вид-во НПУ ім. М. П. Драгоманова, 2006. - 198 с.

УДК $371.134: 80$

Олександра Лисевич

\section{ФОРМУВАННЯ ТВОРЧОЇ ОСОБИСТОСТІ МАЙБУТНЬОГО ВЧИТЕЛЯ ПОЧАТКОВИХ КЛАСІВ}

Лисевич О. В. Формування творчої особистості майбутнього вчителя початкових класів.

У статті розглядається проблема формування творчої особистості майбутнього вчителя початкових класів, підходи та шляхи іiі формування. На думку автора, є необхідність у забезпеченні умов, які сприяли б виявам творчої активності, створення творчого мікроклімату, проблемно-пошукової атмосфери, необхідної для формування позитивних мотивів креативної діяльності. Автор стверджує, що необхідними умовами для вияву творчості в педагогічній діяльності $є$ наявність творчих особистостей, творчого процесу, творчого середовища.

Ключові слова: креативність, творча особистість, творчий потенціал, творчий процес, творче середовище, професіоналізм майбутніх учителів початкових класів.

Лисевич А. В. Формирование творческой личности будущего учителя начальных классов.

В статье рассматривается проблема формирования творческой личности будущего учителя начальных классов. С точки зрения автора, необходимо обеспечить условия, которые способствовали б проявлениям творческой активности, создать творческую атмосферу, необходимую для формирования позитивной мотивации, креативной деятельности. Автор утверждает, що необходимыми условиями для проявления творчества в педагогической деятельности является наличие творческих личностей, творческого процесса, творческой среды.

Ключевые слова: креативность, творческая личность, творческий потенциал, творческий процесс, творческая среда, профессионализм будущих учителей начальных классов.

Lysevich A. V. The creativity as a feature of the professionalism of the future elementary school teacher.

The article reveals the problem of the formation of the creative personality of the future elementary school teacher, and the approaches and means of its formation. The author states that it is necessary to create the circumstances which would stimulate the creative activity, and the creative atmosphere which is of great need for the formation of positive motivation and creative activity. The author also insists that the presence of creative personalities, creative process, and creative environment are the important factors for the realization of the pedagogical creativity in the process of teaching.

Key words: creativity, creative personality, creative potential, creative process, creative environment, the professionalism of the future elementary school teacher.

У сучасній науці спостерігається активізація досліджень щодо розв'язання проблеми творчості, оскільки визнано, що творчі досягнення мають соціальну цінність. Основне завдання науки полягає в розкритті закономірностей і механізмів творчого процесу, креативності (англ. creativity - творчість).

Творчість як основа та механізм розвитку психіки досліджувалась у роботах Н. Кіпіані, О. Матюшкіна, Я. Пономарьова, І. Семенова та ін.; творчість та закономірності мислення розглядались Н. Алексєєвим, С. Бернштейном, В. Біблером, О. Тихомировим, Е. Юдіним. Дослідженням креативності здіснювали Дж. Гілфорд, В. Сміт, К. Тейлор, Е. Торренс, Х. Трік, Д. Халперн та ін.

Більшість дослідників у визначенні креативності роблять акцент на особливостях або специфічних рисах особистості. На думку Дж. Гілфорда, креативність і творчий потенціал можуть бути визначеними як сукупність здібностей, особистісних рис, які сприятимуть успішному творчому мисленню [1]. 